\title{
Pseudoamycolata halophobica gen. nov., sp. nov.
}

\author{
V. N. AKIMOV, LYUDMILA I. EVTUSHENKO, AND SVETLANA V. DOBRITSA* \\ All-Union Collection of Microorganisms, Institute of Biochemistry and Physiology of Microorganisms, \\ USSR Academy of Sciences, Pushchino, Moscow Region, 142292, USSR
}

\begin{abstract}
A new genus and species, Pseudoamycolata halophobica, is proposed for two closely related strains formerly assigned to Amycolata (Nocardia) autotrophica. The following characteristics are important for defining the genus Pseudoamycolata: a type IV cell wall composition (presence of meso-diaminopimelic acid, arabinose, and galactose); lack of mycolates; phospholipid type PII (presence of phosphatidylethanolamine); menaquinone MK-8 $\left(\mathrm{H}_{4}\right)$ as the major menaquinone; iso- and anteiso-branched fatty acids; and a guanine-plus-cytosine content of $72 \mathrm{~mol} \%$. P. halophobica is readily differentiated from morphologically similar members of the genera Amycolata and Amycolatopsis by phospholipid composition and menaquinone composition, respectively. In addition, it can be distinguished from Amycolata and Amycolatopsis species by low levels of deoxyribonucleic acid-deoxyribonucleic acid homology (12 to 15 and 7 to $10 \%$, respectively) and a number of physiological characteristics. The type strain of $P$. halophobica is strain VKM Ac-1069 (= DSM 43089).
\end{abstract}

Actinomycetes which contain meso-diaminopimelic acid, arabinose, and galactose in their cell envelopes (wall chemotype IV sensu Lechevalier and Lechevalier [12]) but lack mycolic acids were considered to form the Micropolyspora aggregate group (5) containing the genera Actinopolyspora, Faenia (Micropolyspora), Pseudonocardia, Saccharomonospora, and Saccharopolyspora, as well as several species of uncertain generic affiliation previously misclassified in the genera Nocardia and Streptomyces. More recently, the taxonomy of this group has changed substantially, and new genera and reclassifications have been proposed. In 1986, three new genera of mycolateless cell wall type IV actinomycetes were described. The genus Kibdelosporangium (15) was proposed to accommodate organisms that produce long chains of aerial spores and sporangiumlike structures, and the genera Amycolata and Amycolatopsis (13) were erected to accommodate mycolateless organisms that were formerly classified in the genus Nocardia. Certain chemotaxonomic characteristics, especially compositions of polar lipids, menaquinones, and cellular fatty acids, have been shown to be of significant value in defining and grouping genera of mycolateless wall chemotype IV actinomycetes $(3,13)$. In particular, the genera Amycolata and Amycolatopsis have been defined mainly on the basis of phospholipid composition (type PIII for the genus Amycolata and type PII for the genus Amycolatopsis) and menaquinone composition [MK$8\left(\mathrm{H}_{2}, \mathrm{H}_{4}\right)$ for the genus Amycolata and MK-9 $\left(\mathrm{H}_{2}, \mathrm{H}_{4}\right)$ for the genus Amycolatopsis] (13).

Amycolata autotrophica, the type species of the genus Amycolata (13), includes about 30 poorly investigated strains of various origins, which were assigned to Nocardia (Amycolata) autotrophica by Gordon et al. (6) primarily on the basis of physiological studies. Our recent taxonomic study (4) showed that some of these organisms should be transferred to a new species, Amycolata alni. Two other strains, strains VKM Ac- $1069^{\mathrm{T}}(\mathrm{T}=$ type strain) and VKM Ac-1078, which were received by us as Amycolata autotrophica, were found to be clearly distinguished from Amycolata species on the basis of their phospholipid pattern (type PII sensu Lechevalier et al. [11]); these strains initially came from M. P. Lechevalier (The Waksman Institute) as Nocardia sp. strains of soil origin (strains $\mathrm{SS} 1 / 1^{\mathrm{T}}$ and $\mathrm{N} 11$,

\footnotetext{
* Corresponding author.
}

respectively). Subsequently, they were assigned to Nocardia autotrophica by Gordon et al. (6).

In this paper we show that these organisms have chemotaxonomic characteristics that preclude their placement in any of the previously described genera of the order Actinomycetales. On the basis of chemotaxonomic, deoxyribonucleic acid (DNA), morphological, and physiological studies, we propose a new genus, Pseudoamycolata, and a new species, Pseudoamycolata halophobica, to accommodate these two mycolateless wall type IV strains.

(Some of the data have been presented elsewhere [V. N. Akimov, S. V. Dobritsa, L. I. Evtushenko, and P. A. Shary, Abstr. 2nd Conf. Taxon. Automatic Identification Bacteria, Prague, Czechoslovakia, 1987].)

\section{MATERIALS AND METHODS}

Bacterial strains. Strains VKM Ac- $1069^{\mathrm{T}}$ (= DSM $43089^{\mathrm{T}}$ $=$ IMRU $1300^{\mathbf{T}}=$ M. P. Lechevalier SS1 $/ 1^{\mathbf{T}}$ ) and VKM Ac-1078 (= DSM 43092 = IMRU $1333=$ M. P. Lechevalier N11) were studied. Type strains of Amycolata and Amycolatopsis species were used for comparison (see Tables 1 and 2).

Phenotypic characterization. Tests for more than 150 characteristics, including morphological, physiological, biochemical, and nutritional tests, were carried out. The methods which we used have been described previously (4).

Cell chemistry. Cell wall, phospholipid, and menaquinone compositions were determined as described previously (4). Cellular fatty acid methyl ethers were prepared and analyzed by gas-liquid chromatography as described previously (4). 2-Hydroxy fatty acids were identified on thin-layer chromatograms as described by Kroppenstedt (9).

DNA characterization. The methods used for preparation and purification of DNA and the conditions used to determine guanine-plus-cytosine $(\mathrm{G}+\mathrm{C})$ contents by the thermal denaturation method and DNA relatedness by the membrane filter method have been described previously $(2,4)$.

\section{RESULTS}

Morphological and cultural characteristics. A study of cultural and morphological characteristics of strains VKM Ac- $1069^{\mathrm{T}}$ and VKM Ac-1078 showed that both of these strains produced white to cream aerial mycelium and yel- 
TABLE 1. DNA base compositions and DNA-DNA homologies among strains of Pseudoamycolata, Amycolatopsis, and Amycolata species

\begin{tabular}{|c|c|c|c|}
\hline \multirow[b]{2}{*}{ Strain } & \multirow{2}{*}{$\begin{array}{c}\mathrm{G}+\mathrm{C} \text { content } \\
(\mathrm{mol} \%)\end{array}$} & \multicolumn{2}{|c|}{ \% Homology with labeled DNA from: } \\
\hline & & $\begin{array}{c}\text { Pseudoamycolata halophobica } \\
\text { VKM Ac-1069 }\end{array}$ & $\begin{array}{c}\text { Amycolatopsis orientalis } \\
\text { VKM Ac- } 866^{\mathrm{T}}\end{array}$ \\
\hline Pseudoamycolata halophobica VKM Ac- $1069^{\mathrm{T}}$ & 72 & 100 & 10 \\
\hline Pseudoamycolata halophobica VKM Ac-1078 & 72 & 61 & 7 \\
\hline Amycolatopsis orientalis VKM Ac- $866^{\mathrm{T}}$ & 66 & 7 & 100 \\
\hline Amycolatopsis mediterranei VKM Ac- $798^{\mathrm{T}}$ & 70 & 10 & 14 \\
\hline Amycolatopsis rugosa IMET $7650^{\mathrm{T}}$ & 67 & 10 & 14 \\
\hline Amycolatopsis sulphurea IMET $7649^{\mathrm{T}}$ & 68 & 7 & 15 \\
\hline Amycolata autotrophica DSM $535^{\mathrm{T}}$ & 72 & 12 & 5 \\
\hline Amycolata alni VKM Ac- $901^{\mathrm{T}}$ & 72 & 12 & $\mathrm{ND}^{a}$ \\
\hline Amycolata saturnea VKM Ac- $781^{\mathrm{T}}$ & ND & 15 & ND \\
\hline
\end{tabular}

${ }^{a}$ ND, Not determined.

lowish orange substrate mycelium. Hyphae broke into rodshaped and oval units. Short chains of spores were produced on the aerial hyphae. In cultures of strain VKM Ac-1078, swollen hyphal segments (up to $3 \mu \mathrm{m}$ long) with transverse and longitudinal septa were often observed, which is characteristic of Amycolata species, Amycolata autotrophica, and Amycolata alni $(4,10)$. Strain VKM Ac- $1069^{\mathbf{T}}$ rarely displayed such structures.

Cell chemistry. A cell wall analysis showed the presence of meso-diaminopimelic acid, arabinose, and galactose, indicating a type IV cell wall composition. No mycolic acids were detected. The principal nitrogenous phospholipid was phosphatidylethanolamine, and phosphatidylmethylethanolamine was present in small amounts; no phosphatidylcholine- or glucosamine-containing phospholipids were detected (type II phospholipid pattern sensu Lechevalier et al. [11]). The principal menaquinone component found in both strains was menaquinone $\mathrm{MK}-8\left(\mathrm{H}_{4}\right)$. As minor constituents, menaquinones $\mathrm{MK}-8\left(\mathrm{H}_{2}\right)$ and $\mathrm{MK}-9\left(\mathrm{H}_{4}, \mathrm{H}_{6}\right)$ were detected in strain VKM Ac- $1069^{\mathrm{T}}$, while menaquinone $\mathrm{MK}-8\left(\mathrm{H}_{6}\right)$ was found in strain VKM Ac-1078. The fatty acids were predominantly saturated branched-chain acids of the iso and anteiso types, as follows (the numbers in parentheses are the percentages of the total fatty acids): iso- $\mathrm{C}_{16: 0}$ acid (19 to 26\%), anteiso- $\mathrm{C}_{17: 0}$ acid (17 to $21 \%$ ), iso- $\mathrm{C}_{15: 0}$ acid ( 7 to $9 \%$ ), and iso- $C_{15: 0}$ acid (5.5 to $\left.9 \%\right)$. Straight-chain saturated $\left(C_{15: 0}\right.$ and $\left.\mathrm{C}_{16: 0}\right)$ and unsaturated $\left(\mathrm{C}_{16: 1}\right)$ fatty acids were detected in amounts ranging from 3 to $8 \%$. 10-Methyl-branched fatty acids (10-methyl- $\mathrm{C}_{17: 0}$ and 10 -methyl- $\mathrm{C}_{18: 0}$ acids) were also present as minor constituents ( 3 to $6.5 \%$ ), including trace amounts (less than $0.2 \%$ ) of tuberculostearic acid (10methyl- $\mathrm{C}_{19: 0}$ acid). 2-Hydroxy fatty acids were also detected by thin-layer chromatography.

DNA characterization. The $\mathrm{G}+\mathrm{C}$ contents of the DNAs of both strains were $72 \mathrm{~mol} \%$ (Table 1). The values for Amycolata species range from 68 to $74 \mathrm{~mol} \%(4,13)$ (Table 1 ), while those for Amycolatopsis species are in the range between 66 and $73 \mathrm{~mol} \%(8,13)$ (Table 1$)$.

Values of 7 to $10 \%$ DNA-DNA homology were found for strains VKM Ac-1069 $9^{\mathrm{T}}$ and VKM Ac-1078 with the type strains of Amycolatopsis species. The levels of homology were slightly higher (12 to $15 \%$ ) with the type strains of Amycolata species. The degree of binding between the DNAs from strains VKM Ac- $1069^{\mathrm{T}}$ and VKM Ac-1078 was 61\% (Table 1).

Physiological characteristics. About $70 \%$ of the 150 physiological characteristics examined were similar for strains VKM Ac-1069 ${ }^{\mathrm{T}}$ and VKM Ac-1078. However, these strains varied in their patterns of utilization of carbon compounds (glycerol, meso-inositol, maltose, sorbitol, sucrose, and benzoic acid), their hydrolytic (hydrolysis of casein) and nitrate reductase activities, and their susceptibilities to some concentrations of antibiotics and growth inhibitors (strain VKM Ac-1078 is more resistant to carbenicillin, erythromycin, gramicidin, lincomycin, monomycin, neomycin, novobiocin, oligomycin, rifampin, ristomycin, streptomycin, tetracycline, and tobramycin). A detailed characterization of the physiological properties is given below in the description of Pseudoamycolata halophobica sp. nov. The physiological characteristics that differentiate Pseudoamycolata halophobica and Amycolatopsis species are shown in Table 2.

\section{DISCUSSION}

Our results show that strains VKM Ac- $1069^{\mathrm{T}}$ and VKM Ac-1078 are characterized by cell wall chemotype IV and the absence of mycolates. Previously, the following eight genera of mycolateless cell wall type IV actinomycetes have been described: Actinopolyspora, Amycolata, Amycolatopsis, Faenia, Kibdelosporangium, Pseudonocardia, Saccharomonospora, and Saccharopolyspora. However, strains VKM Ac- $1069^{\mathrm{T}}$ and VKM Ac-1078 cannot be unambiguously assigned to any of these taxa because these strains have a type PII phospholipid pattern and major menaquinones of the MK- $8\left(\mathrm{H}_{4}\right)$ type, a combination which is different from the combinations of characteristics which define related taxa (Table 3 ).

Upon initial observation, strains VKM Ac- $1069^{\mathrm{T}}$ and VKM Ac-1078 morphologically resemble members of the genus Amycolata, especially Amycolata autotrophica and Amycolata alni $(4,10)$. These strains also have cultural and physiological characteristics, DNA G + C contents, and menaquinone and fatty acid compositions that are consistent with their assignment to the genus Amycolata. However, strains VKM Ac- $1069^{T}$ and VKM Ac-1078 have phospholipid type PII rather than phospholipid type PIII, which is characteristic of the genus Amycolata (13). The difference in phospholipid composition, which is a strong taxonomic criterion, leads us to conclude that these two strains should be excluded from the genus Amycolata.

Accordingly, these strains cannot belong to the genera Actinopolyspora, Faenia, Pseudonocardia, and Saccharopolyspora, members of which have type PIII phospholipid compositions and differ from our strains in a number of other attributes $(1,3,13,16)$ (Table 3$)$.

Three genera of mycolateless cell wall type IV actinomycetes, Kibdelosporangium, Saccharomonospora, and Amycolatopsis, are characterized by type PII phospholipid 


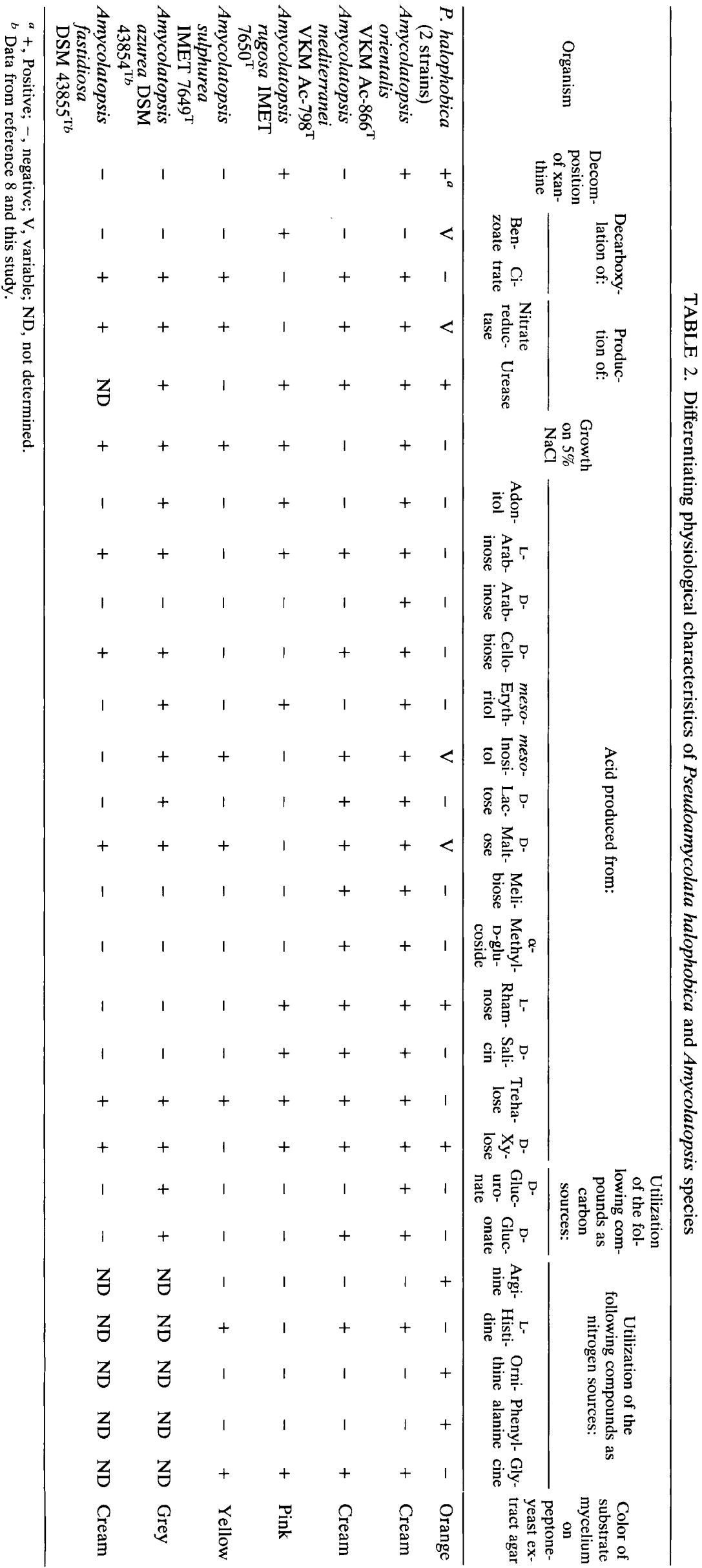


TABLE 3. Chemotaxonomic and DNA characteristics of mycolateless wall type IV actinomycetes ${ }^{a}$

\begin{tabular}{|c|c|c|c|c|}
\hline Genus & $\begin{array}{l}\text { Characteristic } \\
\text { fatty acids }^{b}\end{array}$ & Phospholipid type & Major menaquinone(s) & $\begin{array}{c}\mathrm{G}+\mathrm{C} \text { content } \\
(\mathrm{mol} \%)\end{array}$ \\
\hline Actinopolyspora & $\mathrm{I}, \mathrm{A}, \mathrm{Me}$ & PIII & MK-9(- $\left.\mathrm{H}_{4}\right)$ & 64 \\
\hline Faenia & $\mathrm{I}, \mathrm{A}, \mathrm{Me}, \mathrm{diMe}$ & PIII & MK-9 $\left(\mathrm{H}_{4}\right)$ & $66-68$ \\
\hline Saccharopolyspora & $\mathrm{I}, \mathrm{A}, \mathrm{Me}, \mathrm{diMe}$ & PIII & MK-9 $\left(\mathrm{H}_{4}\right)$ & 69 \\
\hline Pseudonocardia & $\mathrm{I}, \mathrm{A}, \mathrm{Me}, \mathrm{diMe}$ & PIII & $\mathrm{MK}-8\left(\mathrm{H}_{4}\right)$ & $71-72$ \\
\hline Amycolata & $\mathrm{I}, \mathrm{A}, \mathrm{Me}$ & PIII & MK-8 $\left(\mathrm{H}_{2}, \mathrm{H}_{4}\right)$ & $68-74$ \\
\hline Amycolatopsis & $\mathrm{I}, \mathrm{A}, \mathrm{Me}$ & PII & MK-9 $\left(\mathrm{H}_{2}, \mathrm{H}_{4}\right)$ & $66-73$ \\
\hline Saccharomonospora & $\mathrm{I}, \mathrm{A}, \mathrm{Me}$ & PII & MK-9 $\left(\mathrm{H}_{4}\right)$ & $67-69$ \\
\hline Kibdelosporangium & $\mathrm{I}, \mathrm{A}$ & PII & $\mathrm{ND}^{c}$ & 66 \\
\hline Pseudoamycolata & $\mathrm{I}, \mathrm{A}, \mathrm{Me}$ & PII & MK-8( $\left.\mathrm{H}_{4}\right)$ & 72 \\
\hline
\end{tabular}

${ }^{a}$ Data from references $3,4,8,13,14$, and 15 and this study. The DNA base compositions of Pseudonocardia (Pseudonocardia thermophila ATCC $19285^{\mathrm{T}}$ and Pseudonocardia compacta DSM 43592 ${ }^{\mathrm{T}}$ ), Saccharopolyspora (Saccharopolyspora hirsuta ATCC $27875^{\mathrm{T}}$ ), and Saccharomonospora $($ Saccharomonospora viridis ATCC $15386^{\mathrm{T}}$ and Saccharomonospora mesophilica VKM Ac-1249 ) are our unpublished data.

${ }^{b}$ I, Iso; A, anteiso; Me, 10-methyl branched; diMe, 10,15-dimethyl branched.

${ }^{c}$ ND, Not determined.

patterns. Our strains can be readily differentiated from members of the genus Kibdelosporangium $(14,15)$, as its members produce long chains of aerial spores and sporangiumlike structures. Saccharomonospora species can be readily differentiated from strains VKM Ac- $1069^{\mathrm{T}}$ and VKM Ac-1078 by morphological and cultural traits, as well as by menaquinone composition $(1,3,7,13)$ (Table 3$)$.

The strains which we studied correspond closely to the description given for the genus Amycolatopsis by Lechevalier et al. (13), with one distinctive difference. Our strains have predominantly menaquinones of the MK-8( $\left.\mathrm{H}_{4}\right)$ type [versus MK-9 $\left(\mathrm{H}_{2}, \mathrm{H}_{4}\right)$ for Amycolatopsis (13)]. However, the taxonomic position of strains VKM Ac- $1069^{\mathrm{T}}$ and VKM Ac-1078 is not immediately apparent from these data, as other actinomycete genera are known to have menaquinones with variable isoprenoid chain lengths (16). The search for genetic relationships between our strains and the type strains of Amycolatopsis species (Table 1) yielded only insignificant degrees of DNA binding ( 7 to $10 \%$ ), which seems sufficient to warrant separate generic status for strains VKM Ac- $1069^{\mathrm{T}}$ and VKM Ac-1078. It is interesting that homology values were slightly higher (12 to $15 \%$ ) with the type strains of Amycolata species. In addition, strains VKM Ac- $1069^{\mathbf{T}}$ and VKM Ac-1078 have physiological characteristics which clearly differentiate them from all members of the genus Amycolatopsis (Table 2), as well as Amycolata species (4).

In view of the distant genetic relatedness to both Amycolata and Amycolatopsis species and their distinctive chemical and physiological characteristics, we believe that the strains which we studied merit a new genus. This conclusion is supported by the results of a numerical taxonomy study (L. I. Evtushenko, L. G. Tomashevskaya, and P. A. Shary, Mikrobiologiya, in press). Therefore, we propose that strains VKM Ac-1069 and VKM Ac-1078 be classified in a new genus, Pseudoamycolata, as Pseudoamycolata halophobica sp. nov. and that strain VKM Ac-1069 be designated as the type strain of the species. Certain differences in physiological characteristics between strains VKM Ac$1069^{\mathrm{T}}$ and VKM Ac-1078 might be considered as corresponding to the taxonomic rank of species. However, the $61 \%$ level of DNA relatedness between these strains (Table 1 ) indicates that they belong to the same species. Below we give descriptions of Pseudoamycolata gen. nov. and Pseudoamycolata halophobica sp. nov.

Pseudoamycolata gen. nov. Pseudoamycolata (Pseu. do.a.my.co.la'ta. Gr. adj. pseudes, false; M. L. fem. $\mathbf{n}$. Amycolata, a genus of actinomycetes; M. L. fem. n. Pseudoamycolata, false Amycolata). Actinomycetes that form vegetative and aerial hyphae which tend to break down into rod-shaped and oval fragments. Short chains of spores may be produced on the aerial hyphae. Gram positive, non-acid fast. Mesophilic, aerobic, catalase positive. Nonmotile. Type IV cell wall composition (meso-diaminopimelic acid, arabinose, and galactose as diagnostic constituents). Mycolates absent. Type PII phospholipid pattern (phosphatidylinositol mannosides, diphosphatidylglycerol, and phosphatidylethanolamine, as well as small amounts of phosphatidylmethylethanolamine, are present). Saturated branched-chain fatty acids of the iso and anteiso types are predominant; straight-chain saturated, unsaturated, 2-hydroxy, and 10-methyl-branched fatty acids, including tuberculostearic acid (traces), are present as minor constituents. The major menaquinone is $\mathrm{MK}-8\left(\mathrm{H}_{4}\right)$. The $\mathrm{G}+\mathrm{C}$ content of the DNA is $72 \mathrm{~mol} \%$ (as determined by the thermal denaturation method). The type species is Pseudoamycolata halophobica.

Pseudoamycolata halophobica sp. nov. Pseudoamycolata halophobica (ha.lo.pho'bi.ca. Gr. n. hals, salt, the sea; Gr. n. phobos, fear, dread; L. fem. adj. halophobica, saltfearing, referring to the inability to grow in the presence of $3 \% \mathrm{NaCl}$ ). Morphology, chemotaxonomy, and general characteristics are as given above for the genus. In addition, swollen hyphal segments (up to $3 \mu \mathrm{m}$ long) with transverse and longitudinal septa may be observed in cultures. The aerial mycelium is white to cream colored, and the substrate mycelium ranges from yellowish orange to brown, depending on the medium (the color of the substrate mycelium on peptone-yeast extract agar is orange).

Acid is produced from fructose, D-galactose, D-glucose, L-rhamnose, and xylose. Acid production from glycerol, meso-inositol, maltose, sorbitol, and sucrose is variable. No acid is produced from adonitol, $\mathrm{L}$ - and $\mathrm{D}$-arabinose, cellobiose, erythritol, melibiose, $\alpha$-methyl-D-glucoside, raffinose, ribitol, ribose, salicin, and trehalose. Decarboxylates aconitate, formate, lactate, malate, malonate, propionate, pyruvate, sebacate, succinate, and trans-aconitate but not citrate, maleate, and salicylate. Decarboxylation of benzoate is variable. No growth on D-gluconate and D-glucuronate as sole carbon sources. Hydrolyzes arbutin, esculin, xanthine, urea, Tween 40 , Tween 60 , and gelatin but not allantoin and starch; variable results are obtained for hydrolysis of casein. Alanine, arginine, hydroxyproline, ornithine, phenylalanine, proline, threonine, tryptophan, and valine but not glycine, histidine, leucine, lysine, and tyrosine are assimilated as sole nitrogen sources. Production of nitrate reductase is variable.

No growth in the presence of $3 \% \mathrm{NaCl}, 0.001 \%$ sodium 
azide, or $0.000001 \%$ crystal violet. Susceptible to roseofungin $(10 \mu \mathrm{g} / \mathrm{ml})$, polymyxin B $(20 \mu \mathrm{g} / \mathrm{ml})$, fucidin $(1 \mu \mathrm{g} / \mathrm{ml})$, metacycline $(1 \mu \mathrm{g} / \mathrm{ml})$, lincomycin $(10 \mu \mathrm{g} / \mathrm{ml})$, penicillin $(10$ $\mu \mathrm{g} / \mathrm{ml})$, tetracycline $(10 \mu \mathrm{g} / \mathrm{ml})$, and novobiocin $(50 \mu \mathrm{g} / \mathrm{ml})$.

The $\mathrm{G}+\mathrm{C}$ content of the DNA is $72 \mathrm{~mol} \%$.

Isolated from soil.

The type strain is strain VKM Ac-1069 (= DSM $43089=$ IMRU $1300=$ M. P. Lechevalier SS1/1).

Description of the type strain. The description of the type strain is the same as that given above for the species, with the following differences: acid is produced from glycerol and meso-inositol but not from maltose, sorbitol, and sucrose; nitrate reductase negative; no decarboxylation of benzoate; and no hydrolysis of casein.

Additional comments. White et al. (17) have described an actinomycete strain, strain NRRL B-16216, which has the same chemotaxonomic and DNA characteristics as Pseudoamycolata halophobica. Strain NRRL B-16216 has a type IV cell wall composition, no mycolates, a type PII phospholipid pattern, major menaquinones of the MK$8\left(\mathrm{H}_{2}, \mathrm{H}_{4}\right)$ type, and a $\mathrm{G}+\mathrm{C}$ content of $73 \mathrm{~mol} \%$. Its physiological characteristics most closely resemble those of Amycolatopsis orientalis. However, the difference in menaquinone composition and a low level of DNA homology with Amycolatopsis orientalis (11.5\%) have not permitted the authors to assign strain NRRL B-16216 to the genus Amycolatopsis. In our opinion, this strain might belong to the genus Pseudoamycolata.

\section{LITERATURE CITED}

1. Agre, N. S. 1986. Systematics of thermophilic actinomycetes. Biological Center Publications, Pushchino, USSR. (In Russian.)

2. Dobritsa, S. V. 1985. Restriction analysis of the Frankia spp. genome. FEMS Microbiol. Lett. 29:123-128.

3. Embley, T. M., A. G. O'Donnell, J. Rostron, and M. Goodfellow. 1988. Chemotaxonomy of wall type IV actinomycetes which lack mycolic acids. J. Gen. Microbiol. 134:953-960.

4. Evtushenko, L. I., V. N. Akimov, S. V. Dobritsa, and S. D. Taptykova. 1989. A new species of actinomycete, Amycolata alni. Int. J. Syst. Bacteriol. 39:72-77.

5. Goodfellow, M., and T. Cross. 1984. Classification, p. 7-164. In M. Goodfellow, M. Mordarski, and S. T. Williams (ed.), The biology of the actinomycetes. Academic Press, Inc. (London), Ltd., London.

6. Gordon, R. E., D. A. Barnett, J. E. Handerhan, and C. H.-N. Pang. 1974. Nocardia coeliaca, Nocardia autotrophica, and the nocardin strain. Int. J. Syst. Bacteriol. 24:54-63.

7. Greiner-Mai, E., F. Korn-Wendisch, and H. J. Kutzner. 1988. Taxonomic revision of the genus Saccharomonospora and description of Saccharomonospora glauca sp. nov. Int. J. Syst. Bacteriol. 38:398-405.

8. Henssen, A., H. W. Kothe, and R. M. Kroppenstedt. 1987. Transfer of Pseudonocardia azurea and "Pseudonocardia fastidiosa" to the genus Amycolatopsis, with emended species descriptions. Int. J. Syst. Bacteriol. 37:292-295.

9. Kroppenstedt, R. M. 1985 . Fatty acid and menaquinone analysis of actinomycetes and related organisms, p. 173-199. In M. Goodfellow and D. E. Minnikin (ed.), Chemical methods in bacterial systematics. Academic Press, Inc. (London), Ltd., London.

10. Kuimova, T. F., and Y. B. Malishkaite. 1984. Fine structure characteristics of Nocardia autotrophica. Mikrobiologiya 53: 342-345. (In Russian.)

11. Lechevalier, M. P., C. de Bievre, and H. A. Lechevalier. 1977. Chemotaxonomy of aerobic actinomycetes: phospholipid composition. Biochem. Syst. Ecol. 5:249-260.

12. Lechevalier, M. P., and H. A. Lechevalier. 1970. Chemical composition as a criterion in the classification of aerobic actinomycetes. Int. J. Syst. Bacteriol. 20:435-443.

13. Lechevalier, M. P., H. Prauser, D. P. Labeda, and J.-S. Ruan. 1986. Two new genera of nocardioform actinomycetes: Amycolata gen. nov. and Amycolatopsis gen. nov. Int. J. Syst. Bacteriol. 36:29-37.

14. Mertz, F. P., and R. C. Yao. 1988. Kibdelosporangium philippinense sp. nov. isolated from soil. Int. J. Syst. Bacteriol. 38:282-286.

15. Shearer, M. C., P. M. Colman, R. M. Ferrin, L. J. Nisbet, and C. H. Nash III. 1986. New genus of the Actinomycetales: Kibdelosporangium aridum gen. nov., sp. nov. Int. J. Syst. Bacteriol. 36:47-54.

16. Sneath, P. H. A., N. S. Mair, M. E. Sharpe, and J. G. Holt (ed.). 1986. Bergey's manual of systematic bacteriology, vol. 2. The Williams \& Wilkins Co., Baltimore.

17. White, J. M., D. P. Labeda, M. P. Lechevalier, J. R. Owens, D. D. Jones, and J. J. Gauthier. 1986. Novel actinomycete isolated from bulking industrial sludge. Appl. Environ. Microbiol. 52:1324-1330. 